\title{
IMPLEMENTASI KURIKULUM DIFERENSIASI PENDIDIKAN KEWARGANEGARAAN PADA KELAS AKSELERASI PESERTA DIDIK CERDAS INKLUSIF MTSN PONOROGO
}

\author{
Ardian Fahmi Rosydi Karim, M. Mansur Ibrahim, Nurbani Yusuf \\ FKIP Universitas Muhammadiyah Malang, Indonesia \\ Email: ardianfahmi20@gmail.com
}

\begin{abstract}
ABSTRAK
Langkah pertama dalam implementasi kurikulum yang penting ditempuh sekolah adalah penyesuaian dengan ketentuan yang berlaku bagi peserta didik cerdas istimewa serta karakternya, di mana perlakuan yang kurang maksimal dan tidak sesuai dengan karakter peserta didik cerdas istimewa disebabkan terjadinya miss konsepsi serta ketidak sesuaian (lack of it) antara tuntutan yang seharusnya dengan kenyataan pelaksanaan pada saat di kelas. Hal ini yang kemudian menyebabkan perlakuan dan pelayanan pembelajaran pada kelas akselerasi di sekolah menjadi kurang maksimal bahkan kurang berguna untuk mengembangkan potensi peserta didik cerdas istimewa, Penelitian ini mengambil rumusan masalah Bagaimanakah langkah - langkah dalam mengimplementasikan Kurikulum Diferensiasi Pada Mata Pelajaran Pendidikan Kewarganegaraan Kelas Akselerasi Peserta Didik Cerdas Inklusif Yang Dilaksanakan Di MTsN Ponorogo, Apa Saja Kendala Yang Dihadapi Dalam Mengimplementasikan Kurikulum Diferensiasi Pada Mata Pelajaran Pendidikan Kewarganegaraan Kelas Akselerasi Peserta Didik Cerdas Inklusif MTsN Ponorogo, Bagaimana Solusi terhadap Kendala yang dihadapi dalam mengimplementasikan kurikulum diferensiasi pada mata pelajaran. Metode dalam penelitian ini menggunakan pendekatan kualitaif karena memiliki beberapa pertimbangan, yaitu: (1) pendekatan kualitatif lebih mudah apabila berhadapan dengan kenyataan jamak, (2) pendekatan ini menyajikan secara langsung hakikat hubungan antara peneliti dan informan, (3) metode ini lebih peka dan dapat menyesuaikan diri dengan banyak penajaman pengaruh bersama terhadap pola-pola nilai yang dihadapi. Sumber data primer diperoleh hasil wawancara yakni wawancara dengan kepala sekolah, Ketua Program PDCI, Guru PKn, serta siswa kelas VII PDCI. Kemudian data dianalisa secara deskriptif kualitatif. Berdasarkan hasil penelitian terdapat kesesuaian dengan komponen kurikulum seperti: (1) Tujuan, (2) Isi atau materi (Bahan Ajar), (3) Proses (Strategi Mengajar) atau sistem penyampaian dari media, (4) Evaluasi, tetapi Proses Implementasi kurikulum Diferensiasi Pendidikan Kewarganegaraan pada kelas Akselerasi PDCI MTsN Ponorogo mendapatkan beberapa kendala di dalamnya yaitu disebabkan oleh keadaan siswa yang cendurung berfikir cepat tetapi gampang bosan kalau materi yang disampaikan tidak membuat siswa berfikir lebih jauh.
\end{abstract}

Kata kunci: ImplementasiKurikulumDiferensiasi, pesertadidikcerdasinklusif

\begin{abstract}
The first step in the implementation of the curriculum of the school is important are adjustments to the provisions that apply to students are intelligent as well as special characters, where treatment insufficient and not in accordance with special smarter learners character due to the occurrence of miss conception as well as the rendering (lack of it) between the demands that should be with the reality of implementation at the time in class. This then lead to the treatment and service learning on grade acceleration in school becomes insufficient even less useful to develop potential learners are special, intelligent Research takes the outline of the problem How steps-the steps in implementing the Curriculum Differentiation on the subjects of Civics Class Accelerated Learners In an inclusive Smart MTsN Ponorogo, what are the obstacles faced in implementing the
\end{abstract}


Curriculum Differentiation on the subjects of Civics Class Accelerated Learners Intelligent Inclusive MTsN Ponorogo, How solutions to obstacles faced in implementing the curriculum differentiation on subjects.The method used in this research approaches Qualitative because it has several considerations, namely: (1) the qualitative approach more easily when faced with the reality plural, (2) it serves directly the nature of the relationship between researchers and informants, (3) the method is more sensitive and can adjust to a lot of sharpening influences together to patterns of values ??encountered. Sources of primary data obtained by interviews the interviews with principals, Chairman of the PDCI, Citizenship teachers, and students of class VII PDCI. then the data were analyzed descriptively qualitative. Based on the results of the research are conformity with curriculum components such as: (1) Objectives, (2) Content or materials (Subjects), (3) Process (Strategies) or the delivery systems of the media, (4) evaluation, but the process of implementation of the curriculum Differentiation Citizenship Education at PDCI Acceleration class MTsN Ponorogo get some constraints therein is caused by circumstances cendurung students who think fast but easily bored if the material presented does not make students to think further

Keywords: Implementation of curriculum differentiation, inclusive smart learners

\section{PENDAHULUAN}

Kurikulum telah menjadi bagian terpenting dalam dunia pendidikan. kurikulum merupakan seperangkat rencana dan pengaturan mengenai tujuan, isi, bahan pelajaran dan metode yang digunakan sebagai pedoman penyelenggaraan kegiatan pembelajaran untuk mencapai tujuan pendidikan tertentu (Peraturan Pemerintah No. 19. Tentang Standart Nasional Pendidikan. 2005 : 4). Semua aktivitas yang diperentukkan bagi kegiatan pembelajaran untuk siswa di sekolah merupakan suatu grand concept dari sebuah kurikulum.

Kurikulum menjadi kunci utama terlaksananya pembelajaran yang terarah dan efisien. Hal ini dikarenakan kurikulum dijadikan pedoman bagi seorang guru untuk melaksanakan kegiatan pembelajaran. Sehingga tidak mengherankan apabila kurikulum selalu dirombak dan ditinjau kembali untuk mengikuti perkembangan ilmu pengetahuan yang semakin maju.

Kurikulum dikembangkan berdasarkan prinsip bahwa peserta didik memiliki posisi sentral untuk mengembangkan kompetensinya agar menjadi manusia yang beriman dan bertakwa kepada Tuhan Yang Maha Esa, berakhlak mulia, sehat, berilmu, cakap, kreatif, mandiri dan menjadi warga negara yang demokratis serta bertanggung jawab. Untuk mendukung pencapaian tujuan tersebut pengembangan kompetensi peserta didik disesuaikan dengan potensi, perkembangan, kebutuhan, dan kepentingan peserta didik serta tuntutan lingkungan. (Peraturan Menteri Pendidikan Nasional Republik Indonesia No. 22, Tentang Standar Isi Untuk Satuan Pendidikan Dasar Dan Menengah, 2006 : 6).

Desain kurikulum peserta didik berbakat dan berkecerdasan istimewa sangat diperlukan karena kurikulum reguler tidak mencukupi dan tidak cocok untuk peserta didik berbakat dan berkecerdasan istimewa. Seperti yang kita ketahui bahwa peserta didik berbakat dan berkecerdasan istimewa mampu bertindak cepat, berkemampuan belajar mendalam, berkemampuan memanipulasi konsep, berkebutuhan khusus dan memerlukan pembelajaran yang menantang. Hal ini menunjukan bahwa sekolah harus mendesain dan memodifikasi kurikulum khusus yang berbeda dengan kurikulum reguler bagi mereka. Berdasarkan pada 
realita tersebut kurikulum reguler harus dimodifikasi dengan menyusunnya bukan mengurangi atau menambahnya, sesuai dengan kebutuhan dan tingkat intelektualnya.

Undang-undang Sistem Pendidikan Nasional Nomor 20 Tahun 2003 (2003:1013) menjelaskan bahwa :

Warga negara yang memiliki potensi kecerdasaan dan bakat istimewa mendapat layanan pendidikan khusus sesuai dengan kebutuhan dan keunggulannya, mendapatkan pelayanan pendidikan sesuai dengan bakat minat dan kemampuannya serta menyelesaikan program pendidikan sesuai dengan kecepatan belajar masingmasing.

Pelaksanaan pendidikan khusus pada peserta didik berbakat dan berkecerdasan istimewa dilakukan dengan bermacammacam tipe, yaitu acceleration (percepatan), segregation (pengelompokan) dan enrichment (pengayaan) (Tirtonegoro. 2006 : 108). Berdasarkan Pedoman penyelenggaraan pendidikan untuk peserta didik cerdas istimewa selama ini telah dilakukan dengan bentuk program percepatan belajar (akselerasi). Akselerasi dapat diselenggarakan dalam 4 (empat) bentuk pilihan, yaitu kelas biasa, kelas khusus, sekolah khusus, dan Penerapan Sistem Kredit Semester (Keputusan Direktorat Jendral Pendidikan Islam Nomor 1976 Tahun 2014:7-8)

Berdasarkan ketentuan tersebut, MTsN Ponorogo melaksanakan program akselerasi dengan diselenggarakan dalam bentuk kelas khusus, yaitu kelas di mana siswa yang memiliki potensi kecerdasan dan bakat istimewa belajar dalam kelas khusus. Sedangkan waktu yang digunakan untuk menyelesaikan program belajar bagi siswa yang memiliki potensi kecerdasan dan bakat istimewa lebih cepat dibandingkan dengan siswa reguler. Pada satuan pendidikan Sekolah Menengah Pertama (SMP / MTs) yang tadinya ditempuh dalam waktu 3 (tiga) tahun dapat dipercepat menjadi 2 (dua) tahun, yaitu pada awal masuk kelas VII (Tujuh) dan tahun berikutnya langsung kelas IX (Sepuluh).

Kurikulum yang diterapkan di Indonesia dan berlaku sampai saat ini sudah ditentukan bahwa isi kurikulum yang diberlakukan di sekolah harus dikembangakan dari standar nasional pendidikan yang telah ditentukan pemerintah, sehingga perbedaan kurikulum antar sekolah hanya dibedakan oleh indikator yang dikembangkan masingmasing sekolah, sesuai dengan karakter dan kebutuhan peserta didik sekolah yang bersangkutan, dan keunggulan yang ingin dicapai.

Langkah pertama yang penting ditempuh sekolah adalah penyesuaian dengan ketentuan yang berlaku bagi peserta didik cerdas istimewa serta karakternya, di mana perlakuan yang kurang maksimal dan tidak sesuai dengan karakter peserta didik cerdas istimewa disebabkan terjadinya miss konsepsi serta ketidak sesuaian (lack of it) antara tuntutan yang seharusnya dengan kenyataan pelaksanaan pada saat di kelas. Hal ini yang kemudian menyebabkan perlakuan dan pelayanan pembelajaran pada kelas akselerasi di sekolah menjadi kurang maksimal bahkan kurang berguna untuk mengembangkan potensi peserta didik cerdas istimewa.

Kurikulum berdiferensiasi untuk program percepatan belajar dapat dilakukan dengan melakukan modifikasi kurikulum nasional dan muatan lokal dengan cara memodifikasi alokasi waktu, memodifikasi isi/materi, memodifikasi sarana-prasarana, memodifikasi lingkungan 
belajar, dan memodifikasi pengelolaan kelas, Kurikulum program akselerasi di MTsN Ponorogo juga mengikuti pola pengembangan kurikulum diferensiasi tersebut.

Pola diferensiasi kurikulum program akselerasi di MTsN Ponorogo sudah diterapkan sejak awal pembukaan program akselerasi tahun 2009, pola tersebut menjadi embrio yang terus berkembang mengikuti perubahan kurikulum di Indonesia. Pada awal pembukaan program akselerasi sampai sekarang di MTsN Ponorogo masih menggunakan acuan kurikulum KTSP dan mulai mencanangkan kurikulum diferensiasi 2013 pada Pembelajaran akademik ditahun depan yaitu pada tahun demik 2016/2017.

Pengembangan pola kurikulum diferensiasi tersebut terus berjalan dengan berbagai modifikasi. Sehingga kemampuan pendidik serta tenaga kependidikan MTsN Ponorogo akan sangat menentukan hasil yang dicapai dalam kurikulum diferensiasi. Oleh karena itu, penulis sangat tertarik untuk meneliti secara mendalam mengenai pola diferensiasi kurikulum tersebut, yang dispesifikasi lagi dalam implementasinya ketika di sekolah. Melalui penelitian skripsi ini, peneliti mengambil judul implementasi kurikulum diferensiasi pendidikan kewarganegaraan pada kelas akselerasi peserta didik cerdas inklusif MTsN Ponorogo.

\section{METODE}

Penelitian ini digunakan pendekatan kualitatif. Bogdan dan Taylor mendefinisikan metodologi kualitatif sebagai prosedur penelitian yang menghasilkan data deskriptif berupa kata-kata tertulis atau lisan dari orang-orang dan perilaku yang dapat diamati. Dalam penelitian kualitatif tidak boleh mengisolasikan individu atau organisasi ke dalam variabel atau hipotesis, tetapi perlu memandangnya sebagai bagian dari sesuatu keutuhan (Moleong, 2004:4). Syaodih (2009 : 60) menjelaskan penelitian kualitatif adalah suatu penelitian yang ditujukan untuk mendeskripsikan dan menganalisis fenomena, peristiwa, aktivitas sosial, sikap, kepercayaan, persepsi, pemikiran orang secara individual maupun kelompok. Sugiyono (2010:15) mengemukakan bahwa metode kualitatif digunakan untuk mendapatkan data yang mendalam, suatu data yang mengandung makna. Makna adalah data yang sebenarnya, data yang pasti merupakan suatu nilai di balik data yang tampak. Oleh karena itu, dalam penelitian kualitaif tidak menekankan pada generalisasi, tetapi lebih menekankan pada makna.

Peneliti menggunakan pendekatan kualitatif karena memiliki beberapa pertimbangan, yaitu: (1) pendekatan kualitatif lebih mudah apabila berhadapan dengan kenyataan jamak, (2) pendekatan ini menyajikan secara langsung hakikat hubungan antara peneliti dan informan, (3) metode ini lebih peka dan dapat menyesuaikan diri dengan banyak penajaman pengaruh bersama terhadap pola-pola nilai yang dihadapi (Moleong, 2004:9-10).

Desain penelitian yang digunakan pada penelitian yang berjudul Implementasi Kurikulum diferemsiasi Pendidikan Kewarganegaraan Pada Kelas Akselerasi Peserta Didik Cerdas Inklusi MTsN Ponorogo ialah menggunakan pendekatan studi kasus. Salim (2006:116) menyejelaskan pendekatan studi kasus dipahami sebagai pendekatan untuk mempelajari, menerangkan atau menginginkan konteksnya yang alamiah tanpa adanya intervensi pihak luar. Dengan 
menggunakan desain penelitian studi kasus peneliti dapat mempelajari subjek secara mendalam dan menyeluruh.

\section{HASIL DAN PEMBAHASAN}

Implementasi Kurikulum Diferensiasi Pendidikan Kewarganegaraan di MTsN Ponorogo.

a. Tujuan

Pendidikan Kewarganegaraan di MTsN Ponorogo merupakan kelompok mata pelajaran kewarganegaraan dan kepribadian yang dimaksudkan untuk peningkatan kesadaran dan wawasan peserta didik akan status, hak, dan kewajibannya dalam kehidupan bermasyarakat, berbangsa, dan bernegara, serta peningkatan kualitas dirinya sebagai manusia.

Kesadaran dan wawasan termasuk wawasan kebangsaan, jiwa dan patriotisme bela negara, penghargaan terhadap hakhak asasi manusia, kemajemukan bangsa, pelestarian lingkungan hidup, kesetaraan gender, demokrasi, tanggung jawab sosial, ketaatan pada hukum, ketaatan membayar pajak, dan sikap serta perilaku anti korupsi, kolusi, dan nepotisme.

Pendidikan Kewarganegaraan di tingkat MTs bertujuan untuk:

1) Berpikir secara kritis, rasional, dan kreatif dalam menanggapi isu kewarganegaraan

2) Berpartisipasi secara aktif dan bertanggung jawab, dan bertindak secara cerdas dalam kegiatan bermasyarakat, berbangsa, dan bernegara, serta anti-korupsi

3) Berkembang secara positif dan demokratis untuk membentuk diri berdasarkan karakter-karakter masyarakat Indonesia agar dapat hidup bersama dengan bangsa-bangsa lainnya
4) Berinteraksi dengan bangsa-bangsa lain dalam percaturan dunia secara langsung atau tidak langsung dengan memanfaatkan teknologi informasi dan komunikasi.

b. Materi

Materi pada pembelajaran pendidikan kewarganegaraan haruslah menunjang pencapaian kompetensi dasar dengan mempertimbangkan, potensi peserta didik, relevansi dengan karakteristik daerah, tingkat perkembangan fisik, intelektual, emosional, sosial, dan spritual peserta didik, kebermanfaatan bagi peserta didik, struktur keilmuan, aktualitas, kedalaman, dan keluasan materi pembelajaran, relevansi dengan kebutuhan peserta didik dan tuntutan lingkungan, dan Alokasi waktu.

Adapun materi yang di berikan pada pelajaran pendidikan kewarganegaraan kelas Akselerasi PDCI MTsN Ponorogo adalah mencangkup sebagai berikut ;

1) Persatuan dan Kesatuan bangsa, meliputi: Hidup rukun dalam perbedaan, Cinta lingkungan, Kebanggaan sebagai bangsa Indonesia, Sumpah Pemuda, Keutuhan Negara Kesatuan Republik Indonesia, Partisipasi dalam pembelaan negara, Sikap positif terhadap Negara Kesatuan Republik Indonesia, Keterbukaan dan jaminan keadilan

2) Norma, hukum dan peraturan, meliputi: Tertib dalam kehidupan keluarga, Tata tertib di sekolah, Norma yang berlaku di masyarakat, Peraturan-peraturan daerah, Normanorma dalam kehidupan berbangsa dan bernegara, Sistim hukum dan peradilan nasional, Hukum dan peradilan internasional

3) Hak asasi manusia meliputi: Hak dan kewajiban anak, Hak dan kewajiban anggota masyarakat, Instrumen nasional dan internasional

Jurnal Civic Hukum Volume 3, Nomor 2, November 2018, hal. 138-148 
HAM, Pemajuan, penghormatan dan perlindungan HAM

4) Kebutuhan warga negara meliputi: Hidup gotong royong, Harga diri sebagai warga masyarakat, Kebebasan berorganisasi, Kemerdekaan mengeluarkan pendapat, Menghargai keputusan bersama, Prestasi diri, Persamaan kedudukan warga negara

5) Konstitusi Negara meliputi: Proklamasi kemerdekaan dan konstitusi yang pertama, Konstitusi-konstitusi yang pernah digunakan di Indonesia, Hubungan dasar negara dengan konstitusi

6) Kekuasan dan Politik, meliputi: Pemerintahan desa dan kecamatan, Pemerintahan daerah dan otonomi, Pemerintah pusat, Demokrasi dan sistem politik, Budaya politik, Budaya demokrasi menuju masyarakat madani, Sistem pemerintahan, Pers dalam masyarakat demokrasi

7) Pancasila meliputi: kedudukan Pancasila sebagai dasar negara dan ideologi negara, Proses perumusan Pancasila sebagai dasar negara, Pengamalan nilai-nilai Pancasila dalam kehidupan sehari-hari, Pancasila sebagai ideologi terbuka

8) Globalisasi meliputi: Globalisasi di lingkungannya, Politik luar negeri Indonesia di era globalisasi, Dampak globalisasi, Hubungan internasional dan organisasi internasional, dan Mengevaluasi globalisasi.

c. Proses Pembelajaran

Kegiatan pembelajaran dirancang untuk memberikan pengalaman belajar yang melibatkan proses mental dan fisik melalui interaksi antar peserta didik, peserta didik dengan guru, lingkungan, dan sumber belajar lainnya dalam rangka pencapaian kompetensi dasar. Pengalaman belajar yang dimaksud dapat terwujud melalui penggunaan pendekatan pembelajaran yang bervariasi dan berpusat pada peserta didik. Pengalaman belajar memuat kecakapan hidup yang perlu dikuasai peserta didik.

Hal-hal yang harus diperhatikan dalam mengembangkan kegiatan pembelajaran adalah sebagai berikut.

1) Kegiatan pembelajaran disusun untuk memberikan bantuan kepada para pendidik, khususnya guru, agar dapat melaksanakan proses pembelajaran secara profesional.

2) Kegiatan pembelajaran memuat rangkaian kegiatan yang harus dilakukan oleh peserta didik secara berurutan untuk mencapai kompetensi dasar.

3) Penentuan urutan kegiatan pembelajaran harus sesuai dengan hierarki konsep materi pembelajaran.

4) Rumusan pernyataan dalam kegiatan pembelajaran minimal mengandung dua unsur ciri yang mencerminkan pengelolaan pengalaman belajar siswa, yaitu kegiatan siswa dan materi.

d. Evaluasi

Evaluasi atau yang lebih dikenal dengan istilah penilaian ialah suatu proses peenilaian pencapaian kompetensi dasar peserta didik yang dilakukan berdasarkan indikator. Penilaian dilakukan dengan menggunakan tes dan non tes dalam bentuk tertulis maupun lisan, pengamatan kinerja, pengukuran sikap, penilaian hasil karya berupa tugas, proyek dan/atau produk, penggunaan portofolio, dan penilaian diri.

Penilaian merupakan serangkaian kegiatan untuk memperoleh, menganalisis, dan menafsirkan data tentang proses dan hasil belajar peserta didik yang dilakukan secara sistematis dan berkesinambungan, sehingga menjadi informasi yang bermakna dalam pengambilan keputusan.

Amalina, Pembelajaran Kooperatif Tipe Student Teams Achievement Division Untuk Meningkatkan Aktivitas Siswa 
Hal-hal yang perlu diperhatikan dalam penilaian.

1) Penilaian diarahkan untuk mengukur pencapaian kompetensi.

2) Penilaian menggunakan acuan kriteria; yaitu berdasarkan apa yang bisa dilakukan peserta didik setelah mengikuti proses pembelajaran, dan bukan untuk menentukan posisi seseorang terhadap kelompoknya.

3) Sistem yang direncanakan adalah sistem penilaian yang berkelanjutan. Berkelanjutan dalam arti semua indikator ditagih, kemudian hasilnya dianalisis untuk menentukan kompetensi dasar yang telah dimiliki dan yang belum, serta untuk mengetahui kesulitan peserta didik.

4) Hasil penilaian dianalisis untuk menentukan tindak lanjut. Tindak lanjut berupa perbaikan proses pembelajaran berikutnya, program remedi bagi peserta didik yang pencapaian kompetensinya di bawah kriteria ketuntasan, dan program pengayaan bagi peserta didik yang telah memenuhi kriteria ketuntasan.

5) Sistem penilaian harus disesuaikan dengan pengalaman belajar yang ditempuh dalam proses pembelajaran. Misalnya, jika pembelajaran menggunakan pendekatan tugas observasi lapangan maka evaluasi harus diberikan baik pada proses (keterampilan proses) misalnya teknik wawancara, maupun produk/hasil melakukan observasi lapangan yang berupa informasi yang dibutuhkan.

Penilaian dilakukan secara berkelanjutan guna mendapatkan gambaran yang utuh mengenai perkembangan penguasaan kompetensi peserta didik, baik sebagai efek langsung (main effect) maupun efek pengiring (nurturant effect) dari proses pembelajaran. Adapun instrumen yang digunakan dalam teknik penilaian pada mata pelajaran pendidikan kewarganegaraan kelas akselerasi MTsN Ponorogo ialah ;

\begin{tabular}{ll}
\hline Teknik & Bentuk Instrumen \\
\hline Tes terulis & $\begin{array}{l}\text { Tes pilihan :Pilihan ganda, benar salah, } \\
\text { menjodohkan, dll. } \\
\text { Tesaisian : isian singkat dan uraian }\end{array}$ \\
\hline Observasi (pengamatan) & $\begin{array}{l}\text { Lembar observasi } \\
\text { ( lembar pengamatan ) }\end{array}$ \\
\hline Penugasan Individu atau & Pekerjaan rumah \\
kelompok & Proyek \\
\hline Tes Lisan & Daftar pertanyaan \\
\hline
\end{tabular}

Kendala Implementasi Kurikulum Diferensiasi Mata Pelajaran Pendidikan Kewarganegraan MTsN Ponorogo.

Sebagaimana penjelasan dan pemahaman mengenai kurikulum Diferensiasi yang dijelaskan dalam Keputusan Direktorat Jenderal Pendidikan Islam Nomor 1976 Tahun 2014 Tentang Pedoman Penyelenggaraan Program Akselerasi Belajar
Bagi Peserta Didik Yang Memiliki Potensi Kecerdasan Dan/Atau Bakat Istimewa Pada Madrasah yang menyebutkan bahwa Kurikulum Program Akselerasi adalah kurikulum nasional dan muatan lokal yang dimodifikasi dengan penekanan materi esensial dan dikembangkan melalui sistem pembelajaran yang dapat memacu dan mewadahi integritas antara pengembangan

Jurnal Civic Hukum Volume 3, Nomor 2, November 2018, hal. 138-148 
spiritual, logika, etika, dan estetika, serta dapat mengembangkan kemampuan berfikir logistik, kreatif, sistematis, linier, dan konvergen, untuk memenuhi tuntutan masa kini dan masa mendatang.

Pendapat beberapa pakar kurikulum diferensiasi yang menjelaskan bahwa kurikulum diferensiasi adalah kurikulum nasional dan muatan lokal yang telah dimodifikasi dengan mempertimbangkan beberapa hal sebagai berikut : (1) modifikasi alokasi waktu, yang disesuaikan dengan kecepatan belajar bagi siswa yang memiliki potensi kecerdasan dan bakat istimewa; (2) modifikasi isi/materi, dipilih yang esensial; (3) modifikasi sarana-prasarana, yang disesuaikan dengan karakteristik siswa yang memiliki potensi kecerdasan dan bakat istimewa yakni senang menemukan sendiri pengetahuan baru; (4) modifikasi lingkungan belajar yang memungkinkan siswa memiliki potensi kecerdasan dan bakat istimewa dapat memenuhi kehausan akan pengetahuan; (5) modifikasi pengelolaan kelas, yang memungkinkan siswa dapat bekerja di kelas, baik secara mandiri, berpasangan, maupun berkelompok.

Penjelasan di atas dapat disimpulkan bahwa kurikulum diferensiasi adalah kurikulum yang memodifikasi semua aspek kurikulum untuk memenuhi kebutuhan khusus peserta didik dengan kecerdasan istimewa, oleh sebab itu apabila tidak diperhatikan dengan seksama maka akan menimbulkan permasalah yang mengakibatkan kendala dalam hasil belajar yang maksimal oleh peserta didik yang memiliki kecerdasan istimewa tersebut.

Hasil pengamatan yang diperkuat dari wawancara yang dilakukan peneliti, peneliti menemukan kendala yang dihadapi peserta didik dan guru mata pelajaran pendidikan kewarganegaraan MTsN Ponorogo. ada pada materi yang disampaikan oleh guru terlalu banyak, ini dikarenakan materi yang disampaikan oleh guru tidak terdapat modifikasi untuk memilih materi esensial. Sebagaimana dapat kita ketahui dari materi yang disajikan yang dirancang Guru Pendidikan Kewarganegaraan MTsN Ponorogo memang tidak terdapat modifikasi pada materi yang seharusnya dipilih atau dimodifikasi.

Kendala ini memang diakui oleh guru mata pelajaran pendidikan kewarganegaraan MTsN Ponorogo yang menyatakan bahwa ada bebarapa hal alasan untuk tidak melakukan modifikasi materi secara esensial sebagaimana hasil wawancara dengan Bu Sulistyaningsih S.Pd ada beberapa pertimbangan untuk tidak melakukan modifikasi materi secara esensial dikarenakan ada kekhawatiran apabila dilakukan modifikasi maka yang terjadi kita hanya sekedar memberikan pengetahuan saja, sedangkan PKn itu kan juga mengajar pendidikan karakter.

Beberapa data dan informasi yang peneliti dapatkan tersebut maka dapat disimpulkan bahwa kendala dalam mengimplementasikan kurikulum diferensiasi tersebut terdapat pada tidak adanya modifikasi pemadatan materi yang esensial dan apabila dilakukan modifikasi pemadatan materi yang esensial maka resikonya adalah pembelajaran Pendidikan Kewarganegaraan hanya ada Transfer Of Knowladge sekedar memberikan pengetahuan saja, sedangkan untuk menamkan nilai - nilai dan norma - norma yang istilahnya dikenal dengan sebutan Transfer of Value dalam membentuk karakter sulit untuk dicapai oleh peserta didik. 
Upaya Dalam mengatasi kendala Kurikulum Diferensiasi Mata Pelajaran Pendidikan Kewarganegaraan

Berangkat dari penjelasan di atas mengenai kendala implementasi kurikulum diferensiasi pada mata pelajaran pendidikan kewarganegaraan pada kelas akselrasi peserta didik cerdas inklusif MTsN Ponorogo yaitu mengenai tidak adanya modifikasi pemadatan materi yang esensial dan apabila dilakukan modifikasi pemadatan materi yang esensial maka resikonya adalah pembelajaran Pendidikan Kewarganegaraan hanya ada Transfer Of Knowladge atau hanya sekedar memberikan pengetahuan saja, sedangkan untuk menanamkan nilai - nilai dan norma - norma yang terdapat pada materi pendidikan kewarganegaraan atau istilahnya Transfer of Value sulit untuk dicapai oleh peserta didik. Hal ini dikarenakan untuk mencapai sebuah pembelajaran yang mengajarkan nilai - nilai norma yang seharusnya dimiliki peserta didik membutuhkan pengalaman belajar yang cukup panjang waktunya untuk memberikan pemaknaan dalam proses pembelajaran tersebut.

Maka untuk mengatasi kendala tersebut sebagai peneliti ingin memberikan sumbangsih pemikiran yaitu dalam mengimplentasikan kurikulum diferensiasi sejatinya harus terdapat pemadatan materi dikarenakan kebutuhan peserta didik yang mempunyai kecerdasan istimewa sangatlah berbeda dengan siswa regular, sebab ciri khas peserta didik yang mempunyai kecerdasan istimewa tersebut selalu ingin mengetahui hal - hal baru yang menantang pengetahuanya, sebagaimana pendapat beberapa pakar mengenai peserta didik tersebut.

Peneliti menawarkan solusi pemadatan materi dengan cara menentukan materi esensial yang tidak membuang materi yang dianggap tidak perlu, tetapi menggabungkan materi yang dianggap mempunyai kesamaan dan cara berfikir yang urut - urut logis.

Adapun mengenai permasalahan yang timbul akibat adanya modifikasi pemadatan materi yang esensial yaitu mengenai hanya terdapat adanya Transfer Of Knowladge atau hanya sekedar memberikan pengetahuan saja, sedangkan untuk menamkan nilai - nilai dan norma - norma yang berlaku di Indonesia atau istilahnya Transfer of Value sulit untuk dicapai oleh peserta didik. Maka solusi untuk kendala yang timbul ini tidak bisa hanya diwajibkan pada mata pelajaranya Pendidikan Kewarganegaraan saja, sebab kurikulum sekolah yang memaksa adanya pemadatan alokasi waktu pelajaran ini yang sebenarnya menjadi berat untuk dibebankan pada mata pelajaran Pendidikan Kewarganegaraan. Oleh sebab itu, sekolah yang mempunyai andil besar untuk mengatasi kendala ini, yaitu dengan cara mengadakan kegiatan kegiatan sekolah yang bersifat pendidikan karakter semisal, outbond, Pramuka, pondok romadhon, dan kegiatan - kegiatan extra yang lain.

Suatu keuntungan besar dimiliki MTsN Ponorogo karena untuk mengatasi kendala ini seharusnya tidak sulit, sebab ciri khas sekolah ini adalah sekolah agama sehingga pendidikan karakter bercirikan islam nasionalis sudah sangat cukup membekali siswa dalam menanamkan nilai nilai kearah karakter yang diharapkan sebagaimana tugas yang seharusnya ditbebankan pada pembelajaran di Mata Pelajaran Pendidikan Kewarganegaraan.

\section{SIMPULAN}

Berdasarkan hasil penelitian dan pembahasa mengenai Implementasi Kurikulum Diferensiasi Pendidikan 
Kewarganegaraan pada kelas akselerasi peserta didik cerdas inklusif MTsN Ponorogo maka dapat diambil simpulan bahwa.Proses Implementasi kurikulum Diferensiasi Pendidikan Kewarganegaraan pada kelas Akselerasi PDCI MTsN Ponorogo Belum Terdapat Kesesuaian dengan maksud dari pada Kurikulum Diferensiasi sebagaimana dijelaskan dalam Keputusan Direktur Jenderal Pendidikan Islam Nomor 1976 Tahun 20014.

Proses Implementasi kurikulum Diferensiasi Pendidikan Kewarganegaraan pada kelas Akselerasi PDCI MTsN Ponorogo mendapatkan beberapa kendala didalamnya yaitu disebabkan oleh tidak adanya pemadatan materi yang esensial sehingga membuat proses pembelajarn menjadi tidak menantang dan apabila terdapat pemadatan materi maka resikonya adalah hanya terdapat transfer of knowledge sehngga tidak ada transfer of value dalam pembelajaran tersebut, Hal ini dipicu karena keadaan siswa yang cendurung berfikir cepat tetapi gampang bosan kalau materi yang disampaikan tidak membuat siswa berfikir lebih jauh.

Untuk mengatasi kendala tersebut maka seharusnya didalam membuat kurikulum diferensiasi mata pelajaran pendidikan kewarganegaraan tersebut harus ada terdapat pemadatan materi yang esensial dan efektif sehingga materi yang akan disampaikan memicu siswa untuk tertantang mempelajari sebuah materi yang diajarkan, sedangkan resiko terhadap adanya pemadatan materi tersebut sekolah seharusnya bertanggung jawab untuk menutupi kekurangan yang timbul karena kebijakanya tersbut. Oleh sebab itu maka sekolah harus membuat beberapa kegiatan yang terencana dengan baik untuk membentuk karakter peserta didik sesuai dengan kebutuhannya, semisal dengan mengadakan kegiatan outbond, pramuka, dan kegiatan yang mempunyai karakter lainya.

Berdasarkan simpulan tersebut, maka penulis memberikan saran sebagai berikut:Madrasah dalam proses pengembangan kurikulum sebaiknya sering mengadakan sosialisasi atau pelatihanpelatihan untuk guru-guru PKn sebagai pribadi yang memiliki tanggung jawab langsung terhadap kemajuan siswanya agar mampu mengembangkan silabus dan RPP secara mandiri yang sesuai dengan kompetensi mengajarnya.

Madrasah harus lebih memperhatikan proses kegiatan pembelajaran yang terorganisir dan saling berkesinambungan dengan semua mata pelajaran agar peserta didik dapat mencapai ketuntasan belajar yang maksimal.Madrasah harus membuat beberapa kegiatan yang terencang dengan baik untuk membentuk karakter peserta didik sesuai dengan kebutuhannya, semisal dengan mengadakan kegiatan outbond, pramuka, dan kegiatan yang mempunyai karakter lainya.

\section{DAFTAR PUSTAKA}

Keputusan Direktur Jendral Pendidikan Islam Nomer 1976 Tahun 2014 Tentang Pedoman Penyelenggaraan Program Akselerasi Belajar Bagi Peserta Didik Yang Memiliki Potensi Kecerdasasn Dan/Atau Bakat Istimewa Bagi Madrasah

Moleong,Lexy,J. 2004. Metodologi penelitian Kualitatif. Bandung: PT. Remaja

Rosdakarya.

Peraturan Pemerintah Republik Indonesia Nomor 19 Tahun 2005 Tentang Standar Nasional Pendidikan. 
Peraturan Menteri Pendidikan Nasional Republik Indonesia Nomer 22 Tahun 2009 Tentang Standart Isi Untuk Satuan Pendidikan Dasar dan Menengah.

Salim, Agus. 2006. Teori\& Paradigma Penelitian Sosial: Buku Sumber UntukPenelitian Kualitatif. Yogyakarta: Tiara Wacana.

Sugiyono. 2010. Metodologi Penelitian Pendidikan (Pendekatan Kuantitatif, Kualitatif dan $R \& D$ ). Bandung: Alfabeta

Syaodih , Sukmadinata. 2009. Metode penelitian pendidikan. Bandung: PT Remaja Rosdakarya

Undang-Undang Republik Indonesia Nomor 20 Tahun 2003 Tentang Sistem Pendidikan Nasional. 